Article

\title{
Intersectoral and Intermunicipal Cooperation as a Tool for Supporting Local Economic Development: Prospects for the Forest and Wood-Based Sector in Poland
}

\author{
Leszek Wanat ${ }^{1, *(D)}$, Tomasz Potkański ${ }^{2}$, Jan Chudobiecki ${ }^{1}$, Elżbieta Mikołajczak ${ }^{1}$ and \\ Katarzyna Mydlarz ${ }^{1}$ \\ 1 Faculty of Economics and Social Sciences, Poznan University of Life Sciences, 60-637 Poznań, Poland; \\ chudobiecki@up.poznan.pl (J.C.); emikolaj@up.poznan.pl (E.M.); kmydlarz@up.poznan.pl (K.M.) \\ 2 Institute of Public Policies, Collegium Civitas in Warsaw, 00-901 Warszawa, Poland; \\ tomasz.potkanski@civitas.edu.pl \\ * Correspondence: leszek.wanat@up.poznan.pl
}

Received: 15 June 2018; Accepted: 24 August 2018; Published: 31 August 2018

\begin{abstract}
Intersectoral and intermunicipal cooperation are still underdeveloped spheres of public and economic development policies. This also applies to the natural economy to a large extent. Scientific discussions are invariably focused on pro-competitive activities, the economic efficiency of which is not always sufficient. In this paper the authors attempt to identify factors leading to cooperation between local government authorities and economic entities focusing on the forestry and wood-based sector in Poland. These processes were analyzed within the framework of the Spatial Economics and New Institutional Economy, both in the theoretical and practical context. The aim of the research was to identify the ability to create intersectoral and intermunicipal partnerships in already existing and newly established functional areas, as this may determine the development of the forestry and wood-based industry.
\end{abstract}

Keywords: forest and wood-based sector; partnership; intersectoral and intermunicipal cooperation; new institutional economy; Poland

\section{Introduction}

Due to the changes of conditions and factors shaping local and regional development that are taking place in Poland and in Europe, it is important to analyze institutional and economic relationships between the entities influenced by these changes. Moreover, in conducting research on intermunicipal relationships and on intersectoral relations, we shall use similar methodologies and tools. Significant changes emerge between institutional relations and market relations, and they are no longer constrained by administrative borders between municipalities. The direction and strength of development processes in a given territory depend on a number of factors, including, for example:

- cultural changes (including needs and expectations of inhabitants);

- changes in competitive situation (social and economic);

- innovativeness and development of new technologies;

- changes of local competitive potential (self-governments, entrepreneurs, households).

These observations, which are a starting point for research reflection, are based on the spatial economics theory, drawing on von Thünen's (1826) [1] (location theory) (Sinclair, 1967) [2] and Weber's (1909) [3] (industrial location models) output, Christaller (1933) [4] (theory of core and periphery), Hotelling (1929) [5] (models of location) and Lösch (1938) [6] (theory of economic 
region) (Jones, 2017) [7], and consequently regional science [8] and new economic geography [9,10]. Moreover, reference was made to current studies combining network analysis [11] with regional competitiveness [12], the mutual interpenetration of globalization and glocalization approaches [13-15], and consequently seeking a relatively optimal path of integrated local development $[16,17]$.

Such a set of factors referring to local development challenges seems insufficient. Obviously the competitiveness of the local economy, availability and attractiveness of services (social, technical, etc.) for local inhabitants, and most of all the quality of local human capital, are still the most important factors of development. Besides them there are clear development barriers which-to a different extent-determine the functioning of municipalities or sub-regions, in connection with the economic activity of enterprises and everyday life of their inhabitants. A starting point for local development programming should be seeking new dynamic factors, which are not limited to local resources, but rather are related to intermunicipal and intersectoral cooperation. A development policy based only on competition is no longer sufficient and often leads to opposite effects to those intended.

The authors of this paper have attempted to verify the hypothesis which assumes the growing importance of development factors built on the basis of cooperation models, and not only resulting from the requirements of competitiveness. Based on their own research studies, the authors have analyzed the ability for advancing local development based on cooperation principles, on the example of an important sector of the economy in Poland, i.e., the forest and wood-based sector. Selected factors of cooperation between local authorities and economic entities for the benefit of territorial development were examined in this context.

Therefore, the aim of the research was to identify the ability to create intersectoral and intermunicipal partnerships in functional areas that have significant importance for forest and wood management in Poland. For this purpose, the analysis of values of the Aggregated Development Index (ADI) proposed by the authors was used in order to compare its spatial diversity with the map of forest potential in Poland. The collection and comparative analysis of such data is crucial for sectoral policy in forestry and related industries. Due to the strong influence of forestry and the wood-based sectors for the development of the Polish economy and the wood market, as well as on international trade, the search for economic development stimulators was considered an important objective for scientific research. It has both cognitive significance (for understanding of regional development, and the economics of this particular industry) and practical significance (for forestry, and all wood-based industries and this in an international perspective), as well as being a part of the current research on sustainable and integrated development.

\section{The Importance of the Forest and Wood-Based Sector for Regional Development in Poland}

When analyzing the importance of the forest and wood-based sector, it is appropriate first to consider the role of forest resources. Forests cover more than 4 billion hectares of the world's total surface area, which means approximately 0.6 ha of forests per capita. The surface area of forests in Poland totals 9.3 million hectares- $-2.23 \%$ of the global surface area of forests (55th place) and $6 \%$ of the surface area of forests in Europe (10th place). The forest ratio in Poland (in relation to its land surface area) is $29.3 \%$. This value is close to the average forest ratio in the world $(29.6 \%)$ and to the forest ratio in Europe, which is $30.3 \%$ (excluding Russia). Moreover, standing timber resources in Poland constitute $9.5 \%$ (2.3 billion cubic metres) of all forest resources in the European Union (4th place in EU) [18].

The Polish wood industry plays an important role in the development of the economy. The most important sectors based on wood include: the sawmill industry, furniture industry, cellulose and paper industry, market of wood-based panels. This industry is highly fragmented and focuses on small- and medium-size businesses (there are only a few large enterprises). A significant number of micro-enterprises (covering approx. $30 \%$ of the entire sector) are not included in any official statistics. The share of the wood-based industry in the production of the entire Polish processing industry is more than $9 \%$. The wood industry processes more than 37 million cubic meters of round timber on 
average per year, purchased mainly from National Forest Holding "State Forests" and worth more than PLN 7 billion (For comparison, the current average exchange rate is 1 USD = 3.9164 PLN (source: http:/ / www.nbp.pl/homen.aspx?f=/kursy/ratesa.html-accessed 2 March 2018)). The potential of the wood industry is additionally confirmed by the level of employment-more than 260,000 employees (including 124,000 in the furniture industry and 49,000 in the paper industry). The production value in the wood-based sectors exceeds PLN 90 billion (including PLN 32 billion in the paper industry and PLN 28.3 billion in the furniture industry); the upwards trend is maintained. The export value of the wood industry products in Poland totals more than EUR (For comparison, the current average exchange rate is 1 EUR = 43796 PLN (source: http:/ / www.nbp.pl/homen.aspx?f=/kursy/ratesa.html—accessed 2 March 2018)) 15 billion with an upwards trend. Export of furniture dominates and reaches the value of PLN 6.7 billion. Poland is the fourth largest exporter of furniture in the world (following China, Italy and Germany), while other EU countries are the main recipient of Polish furniture (more than $80 \%$ of export value) [18].

The competitive position of the Polish wood-based sectors is relatively strong. It is an effect of forest resources, the quantity and quality of round timber acquired from the national resource base, as well as continually growing significance of wood-based products in global production and trade. Despite the imbalance in the Polish wood market and the deficit of the wood raw material (a permanent phenomenon being an effect of the application of the principles of sustainable forest management), there is no threat for the development of wood-based industries in Poland. The following factors have a decisive impact on the following: dynamic increase in the demand for wood, wood products and popularity of wood as an environmentally and human friendly raw material [19-22]. A study of intersectoral and intermunicipal relationships - as potential factors of development-seems justified with reference to the wood-based sector, especially owing to its territorial dispersion.

\section{Dilemmas of Intersectoral and Intermunicipal Cooperation for the Benefit of Development}

The gradual exhausting of resources which were the basis of local and regional development in Poland after 1989 is observed [23]. These resources include: income generated by traditional sectors of economic activity, unutilized land and facilities, unused human resources. Revenues from sale of property in the conditions of relative short-term economic prospects, European Union funding and credits (i.e., one-time or short-term income) have been used to finance local development up to this date. At the same time, the scope of tasks of regional and local authorities has increased; changes resulting from globalization processes are taking place in the economy; local communities are getting older and population numbers are actually going down. Demographic changes result from a drop in the birth rate and unfavorable migration tendencies. At the same time, these aspects are the cause and effect of cultural, systemic and structural changes in the economy. It seems that in the face of challenges associated with globalization and glocalization (Glocalisation "expresses the way globalization dynamics - are always reinterpreted locally, leading to an interpenetration of the local and global scales that created context-dependent outcomes". Some authors $[13,15]$ go so far "as to consider that glocalisation in the way that globalisation really operates". Like the other "dynamics of globalisation, glocalisation also takes place in different fields" (first of all, in the field of culture and economics) [24]), the human being (human capital) becomes the key factor of the development (See the research work in the field "The Interdisciplinary Nature of the New Paradigm of Development-Considerations and Proposals for Improving the Dialogue ... ") [16], rather than rules of competition.

Functioning in changing conditions requires integration and improvement of the territorial development management system and this should happen on the initiative of local authorities. Based on already conducted analyses, it was considered to be the starting point [25] to monitor and evaluate changes taking place inside local communities and in functional areas created by municipalities which are mutually related in their economic and social development. This monitoring and evaluation function should cover as follows: 
- assessment of municipality's development potential within the scope of functional area it belongs to;

- redefinition of the role of a municipality within this functional area;

- permanent adjustment of infrastructure, economy and services in a given functional area to dynamically changing needs.

At least some local development barriers have been identified within this context, including:

- a change of a traditional economy model to a knowledge-based economy;

- outflow (internal migration) of the most talented inhabitants to other cities and regions;

- urban sprawl and escape of inhabitants of city centers to suburban areas (The case of big cities);

- a necessity for permanent education and constant adjustment of employees' potential to structural changes and expectations of the labor market;

- a growing level of social inequalities, being a result of technological, economic and cultural exclusion in local communities;

- a limited offer of local services (based on infrastructure rather than social resources) with a dropping impact on the quality of life of inhabitants;

- a relatively low level of collaboration between local authorities, social partners and entrepreneurs in the local and regional dimension.

It is worth comparing the indicated barriers with the thesis formulated by Richard Florida, the author of "Who is Your City?", who tries to convince that the possibilities of local development are influenced to a large extent by an ability to attract young inhabitants. The winning places are the ones that become appealing for the young [26]. Actually, research studies confirm that sudden and rapid development is observed in places where young people migrate and settle. This view, in conjunction with the results of studies in local self-governments, leads to an interesting conclusion-namely, local development will probably be determined by a creative economy, in particular the force of combining the quality of an offer for young people with the level of intersectoral cooperation in functional areas. With reference to sectors of the economy, including the wood-based sector, challenges in terms of building intersectoral cooperation have been identified in three main areas [27] as follows:

- $\quad$ establishing and developing small and medium-size businesses;

- research and creative economy (innovations);

- $\quad$ efficient energy and use of renewable energy sources.

In the light of various observations it is required to improve the effectiveness of providing public services in collaboration with partners (process innovations) and the use of modern technologies (product innovations). It is extremely difficult to work out and implement an effective development policy without being focused on cooperation, competition and constant exchange of experiences between partners from various sectors.

The research refers to network theory, and consequently to the network analysis and SNA (Social Network Analysis) as well as ONA (Organizational Network Analysis) methodologies [28]. The starting point for the study of network connections is the correct definition of the network structure [29]. The aim is to designate a relatively independent, closed set of participants on the basis of specific, defined criteria (delimitation). The difficulty of identifying networks depends also on the fact that their participants (stakeholders) have limited opportunities to influence the network. It has been noted that network structures are not so much the result of the conscious development created by the participants, as these emerge in a certain way [30]. These difficulties lead to the search for such methods of measurement that would allow to identify the real networks of cooperation and to assess the ability to create the above-mentioned networks effectively [31,32]. 


\section{Sample Assessment of the Conditions of Intersectoral and Intermunicipal Cooperation in Poland-Material and Methods}

Each settlement unit (e.g., a municipality) is a part of a specific functional area. Therefore, the addressee of the development policy should be not only an administrative unit, but a functional area which may create many administrative units, and entities operating within a given territory. It is hard to imagine development of functional areas without the support of partnership tools. There are no comprehensive regulations in Polish law which would organize the matter of cooperation between local government units, both in the intermunicipal and intersectoral aspects.

In the designed research scenario, the local government units in Poland (LGUs) were taken into account, compiled by groups/types in Table 1 [the subjective scope of the research]. The potential ability of these entities to undertake cross-sectoral cooperation within the functional areas [the objective scope] was identified. The analysis was carried out for Poland [the spatial scope], looking for common points especially for those territories that coincide with areas of strong natural resource potential of the Polish forestry and wood-based industries. The comparative analysis was performed for the period of 2008-2014 [the time range]. Selected network analysis tools were used, based first on the authors' research [33,34]. Analyses of modular structures and knowledge engineering [35] as well as connectomics achievements [36] were referred to. In particular, the components of the cooperation model (Section 4.1) and the spatial diversification of the synthetic measure, determined by the Aggregate Development Index (ADI) (Section 4.2) were analyzed in order to attempt the spatial visualization of the growth potential map of intersectoral partnerships in Poland (Figure 1).

Table 1. Changes to the Aggregated Development Index ADI ${ }_{L G U}$ value in the years 2008-2014.

\begin{tabular}{|c|c|c|c|c|c|}
\hline \multicolumn{6}{|c|}{$\mathrm{ADI}_{\mathrm{LGU}}$ Changes in the Years 2008-2014 in Poland } \\
\hline LGU (Municipalities) & Drop ADI & Growth ADI & \multirow{6}{*}{ TRENDS } & Change ADI & $\begin{array}{c}\text { Number } \\
\text { Municipalities }\end{array}$ \\
\hline $\begin{array}{c}\text { Big cities } \\
\text { (with county rights) }\end{array}$ & $60(91 \%)$ & $6(9 \%)$ & & $\begin{array}{l}\text { More than } 5 \text { points } \\
\quad \downarrow<-13 ;-5>\end{array}$ & 47 \\
\hline Municipalities (other) & $188(79 \%)$ & $50(21 \%)$ & & $\begin{array}{l}\text { Less than } 5 \text { points } \\
\downarrow \downarrow<-5 ; 0>\end{array}$ & 1105 \\
\hline $\begin{array}{l}\text { Urban-rural } \\
\text { municipalities }\end{array}$ & $307(50 \%)$ & $304(50 \%)$ & & $\begin{array}{l}\text { Less than } 5 \text { points } \\
\qquad \uparrow<0 ;+5>\end{array}$ & 1315 \\
\hline Rural municipalities & $597(38 \%)$ & $967(62 \%)$ & & $\begin{array}{l}\text { More than } 5 \text { points } \\
\quad \uparrow<+5 ;+28>\end{array}$ & 12 \\
\hline \multicolumn{2}{|c|}{$\begin{array}{l}\text { Selected intersectoral partnerships in } \\
\text { the forest- and wood-based sector }{ }^{1}\end{array}$} & $\uparrow 58 \%$ & & \multicolumn{2}{|c|}{$\begin{array}{c}2479 \text { (100\% LGU/municipalities in } \\
\text { Poland (2014)) }\end{array}$} \\
\hline \multicolumn{6}{|c|}{$\begin{array}{l}{ }^{1} \text { The Index value estimated statistically-representative sample-of partnerships in the forest and wood-based } \\
\text { sector, working in } 5 \text { regions: Opole, Szczecin, Zielona Góra, Koszalin and Olsztyn [37]. The formulated } \\
\text { sub-model-for the forest and wood-based sector-explains } 58 \% \text { of the variability of predictor Y (endogenous } \\
\text { variable), which is the value of the Aggregated Development Index ADILGU (confidence level } 90 \% \text {, fraction size 0.5, } \\
\text { and maximum error of estimate } 10 \% \text {. There was a trend similar to that for all municipalities (rural) [37-39]. Source: } \\
\text { author elaboration based on Potkański (2016, 40-42) [33]. }\end{array}$} \\
\hline
\end{tabular}

For the sake of the research, several institutional forms of cooperation with the participation of local government units have been identified. These include as follows: unions of local government units, metropolitan unions, agreements of local government units, associations with the participation of local government units (including local action groups) and commercial companies with the participation of local government units. Cooperation may also be established under public-private partnerships in case of single projects. Other forms of cooperation are regulated by contractual freedom under civil law; these are the basis for the following: consortia, clusters, agreements on mutual cooperation and exchange of experiences. Their application, however, is characterized by limited coverage, mainly due to institutional barriers. The Polish legal system does specify a universal 
formula of institutional cooperation. The differences in functioning structures are linked among others with the following:

- partnership composition and mode of partner selection;

- objectives of partnership operations;

- scope of obligations and responsibilities;

- methods of financing;

- flexibility in the shaping of cooperation rules.

Legal provisions determine to a large extent the Polish model of intermunicipal and intersectoral institutional cooperation [33].

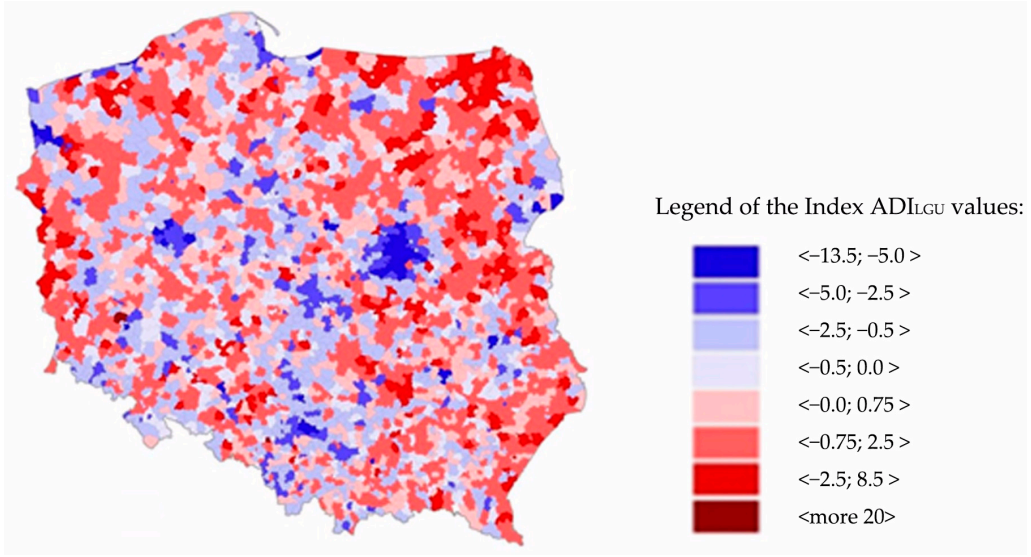

Figure 1. The variation of the value of the Aggregated Development Index municipalities in Poland (difference 2008-2014). Source: Potkański (2016), pp. 41, based on: Porawski A., Potkański T., Czajkowski J.M., Szewczuk J., Ogólna charakterystyka stanu i uwarunkowań współpracy jednostek samorząu, http:/ / partnerstwasamorzadowe.pl/repozytorium/czytaj/publikacja-pt-wspolpraca-jstwsparciem-polskiej-polityki-rozwoju/, accessed: 21 April 2018 [33].

\subsection{The Pillars "Model of Cooperation"-Discussion of the Partnership Paradigm}

A new proposal for a cooperation model results from research studies regarding various factors of intersectoral and intermunicipal cooperation (Table 2). The proposal refers to research on the factors of network cooperation, based on knowledge and cooperation [34,40-43].

The model describes a desired set of cooperation mechanisms in key aspects of a partnership's functioning. These aspects, in the form of scenarios enabling evaluation of partnership quality, have been presented as 10 standards of institutional cooperation. Seven standards refer to strategic management of territorial development, while the remaining three are associated with operational management of relationships within a partnership. An integrated partnership requires a combination of aspects of the strategic and operational development of the 10 areas, determined by the "canons" of cooperation model standards (see Table 2).

In this perspective, a combination of qualitative and quantitative approaches has proved necessary. The proposed ADI Index has been adapted to the research, adequately to the specificity of functional areas, integrating economic, natural and social role. The correctness of component decomposition was confirmed by research conducted by Chudobiecki, Potkański and Wanat (2016, pp. 187-196) [44], as well as by analyses based on a multifactorial model verified by retrospective regression, proposed by Popek and Wanat (2014, pp. 71-77) [45]. Of course, ADI is not the only, exclusive measure. It is necessary not only to constantly examine the variability of the ADI index, but also to continue the search for the measure that is as close to optimal as possible. Research in this area is continued, referring, inter alia, to the scientific papers of Paulo Reis Mourão [46,47], related to the discussion on the Puviani's Fiscal Illusion Index. 
Table 2. The 10 areas determined by the "canons" of intersectoral cooperation model standards.

\begin{tabular}{cll}
\hline \multicolumn{2}{c}{ The "Canons" of Intersectoral Cooperation Model Standards } \\
\hline I. & $\begin{array}{l}\text { Partnership composition (a team adjusted to } \\
\text { cooperation objectives) }\end{array}$ & $\begin{array}{l}\text { Objective-oriented cooperation of entities from } 3 \text { sectors } \\
\text { (public, social and economic) }\end{array}$ \\
\hline II. & $\begin{array}{l}\text { Partnership's potential (a diagnosis of resources } \\
\text { and developmental needs of a functional area) }\end{array}$ & $\begin{array}{l}\text { A constant diagnosis of a functional area and identification } \\
\text { of development factors are the foundation of cooperation }\end{array}$ \\
\hline III. & A network of functional connections & $\begin{array}{l}\text { The potential of functional connections in the scope of public } \\
\text { services and market activity on the territory of a partnership }\end{array}$ \\
\hline IV. & $\begin{array}{l}\text { Development programming (sectoral strategies and } \\
\text { programs) }\end{array}$ & $\begin{array}{l}\text { Implementation of strategies and programs of functional } \\
\text { area development }\end{array}$ \\
\hline V. & $\begin{array}{l}\text { Integration of services and infrastructure } \\
\text { (coordination of resources and public services) }\end{array}$ & $\begin{array}{l}\text { The level of infrastructure and service integration within a } \\
\text { functional area is considered the measure of development }\end{array}$ \\
\hline VI. & $\begin{array}{l}\text { Integration and operationalization of development } \\
\text { strategies (for a partnership and for partners) }\end{array}$ & $\begin{array}{l}\text { The compliance of strategic and operational documents of } \\
\text { all partners with development priorities }\end{array}$ \\
\hline VII. & Monitoring and evaluation & $\begin{array}{l}\text { Permanent assessment of partnership's performance and } \\
\text { effectiveness }\end{array}$ \\
\hline VIII. & External relationships & Operational dimension (management of relationships in a partnership) \\
\hline X. & Mutual trust & $\begin{array}{l}\text { Partnership's communication with inhabitants and other } \\
\text { stakeholders is a tool enabling to build social trust }\end{array}$ \\
\hline & Space for debate and internal communication & $\begin{array}{l}\text { Professionalism and transparency of debate as well as } \\
\text { quality of dialogue in a partnership are considered criteria of } \\
\text { cooperation development }\end{array}$ \\
\hline $\begin{array}{l}\text { Relationships in a partnership are based on: Mutual trust, } \\
\text { equal treatment and just distribution of responsibilities } \\
\text { between all "actors" }\end{array}$
\end{tabular}

The Aggregate Development Index $\left(\mathrm{ADI}_{\mathrm{LGU}}\right)^{1}$

${ }^{1}$ A model of the Aggregated Development Index (for local government units) [Potkański 2016]. Source: Author elaboration based on Potkański 2016, pp. 127-163 [33].

One of the measures supporting the process of evaluation is the so-called Aggregate Development Index (Potkański, 2016, pp. 36-42) [33], of which values were analyzed for the tested territorial units (in this case: municipalities).

\subsection{The Aggregated Development Index-Results of Comparative Analysis}

A model of the Aggregated Development Index (for local government units \{LGUs\}), can be presented in the following manner:

$$
\mathrm{ADI}_{\mathrm{LGU}}=\mathrm{f}(\mathrm{Q})\left\{\mathrm{Q}_{1} ; \mathrm{Q}_{2} ; \mathrm{Q}_{3} ; \mathrm{Q}_{4} ; \mathrm{Q}_{5} ; \mathrm{Q}_{6} ; \mathrm{Q}_{7} ; \ldots \mathrm{Q}_{n}\right\}
$$

Individual symbols mean as follows:

$\mathrm{ADI}_{\mathrm{LGU}}$-Aggregated Development Index (based on the model);

$\mathrm{Q}_{1}$-Wealth of inhabitants;

$\mathrm{Q}_{2}$ - Level of economic activity;

$\mathrm{Q}_{3}$-Infrastructural space productivity;

$\mathrm{Q}_{4}$-Local real estate market potential;

$\mathrm{Q}_{5}$-Demographic potential;

$\mathrm{Q}_{6}$ - Level of social development (the most—destimulant);

$\mathrm{Q}_{7}$-Demographic burden (the most—destimulant);

$\mathrm{Q}_{n}$-Additional measures (the most-specific determinants).

The value of the Index is composed of at least 7 main elements, which reflect individual components of a municipality's potential (functional area). These include: (1) wealth of inhabitants 
(PIT per capita), (2) level of economic activity (CIT per capita), (3) infrastructural space productivity, (4) local real estate market potential, (5) demographic potential (the so-called Creativity Index by Richard Florida) —as stimulants, and (6) level of social development (unemployment) and (7) demographic burden —as destimulants. The catalogue of components is an open set, permanently infinite, dependent on the individual features of a functional area.

The value of the Aggregated Development Index was calculated as a sum of standard deviations for particular components. The components were not given any weights, to make the process simpler. The "Z-scores" method was applied, which enabled determination of the aggregate value of the index as a sum of standardized values of partial components (Potkański, 2016, pp. 40-42) [33]. Selected results were illustrated in a table and graphically (see Table 1 and Figure 1).

\subsection{LDI Index Variability Analysis Results Discussion-the Growth Potential Map of Intersectoral Partnerships in Poland}

In the examined period from 2008 to 2014, a drop in the Aggregated Development Index was observed in general for 1152 municipalities (the drop was significant in the case of 47), while an increase of the Index value was identified for 1327 municipalities (including a significant increase in the case of 12). This increase refers mainly to rural municipalities.

No significant change was observed for urban-rural municipalities. Meanwhile, a substantial drop of the Index value was observed for towns and cities (including mainly 60 towns and cities with county rights). Moreover, a relatively constant level of the PIT per capita component was observed, with a simultaneous significant rise of the total dependency ratio (demographic burden) (Potkański, 2016, pp. 40-42) [33].

Referring to the competitive situation of forestry and the wood-based sector in Poland, it was noted that just the "imposition" of the growth potential map of intersectoral partnerships in Poland on the map of forest resources allows for identification of the relative strength of convergence and even a large degree of overlapping of areas with significant potential both for the wood-based industry and the development of cooperation (intersectoral and intermunicipal partnerships). The fact that this observation concerns, and does not exclude, rural areas should be regarded as a strategic opportunity from the point of view of development policy. Indeed, the authors are aware that discussing and visualizing the results of the detailed analysis requires a separate study.

It should be added here that research on spatial autocorrelation is being continued in order to identify functional areas for which development potential, based on the potential for cross-sectoral cooperation and the resources of the wood-based industry, is showing an upward trend; in this context, spatial relations related to the certification of wood and forest areas are also being studied, providing an opportunity to gain competitive advantages for functional areas based on wood [48].

Identification of spatial autocorrelation in the selected territorial units (e.g., local government units-LGUs) allows to state that this phenomenon influences the occurrence of a similar trend (with an increasing or decreasing direction) in neighboring units [49,50]. This conclusion is based on the "Waldo Tobler's First Law of Geography" [51], from which the phenomenon of spatial interdependency is derived, inter alia, using IMoran's statistics and local spatial dependence indicators, referring to the LISA (Local Indicators of Spatial Association) method proposed by Anselin (1995) [52]. Spatial autocorrelation statistics, by providing information on the type and strength of spatial dependence, enable the determination of relationships between the surveyed units and the identification of spatial (functional) structures with greater accuracy than traditional measures.

The selected examples of intersectoral partnerships [33,44], co-established by entities from the forest and wood-based sector, were taken out of a multiple case study and included in a comparative analysis. In places where an intersectoral partnership was functioning effectively, a significant increase of the Aggregate Development Index for a given functional area was observed in the analyzed period. Moreover, shifting tax "productivity" from cities to neighboring areas, including 
suburbs (local migration and urban sprawl), constitutes an argument in favor of intersectoral cooperation development.

\section{Conclusions}

The following conclusions could be formulated:

1. Potential and development capabilities of the functional areas under investigation is of essential importance for the regions' economic development, especially for industries characterized by high territorial fragmentation, i.e., the forest and wood-based sector in Poland.

2. An analysis of changes in the Aggregate Development Index values makes it possible to identify the functional areas and municipalities which possess the capacity to establish intersectoral partnerships. Comparing the map of spatial diversity of the Aggregate Development Index with the map of forest resources potential and the location of entities from the forest and wood-based sector makes it possible to indicate additional criteria for the development of intersectoral partnerships with the participation of forest management.

3. Institutional conditions of intermunicipal and intersectoral cooperation in Poland are concurrently an opportunity and a barrier for the establishment of partnerships with the participation of the forest and wood-based sector. The model based on the "canons" of cooperation quality assessment standards may constitute a tool enabling the evaluation of the opportunities for the development of intersectoral partnerships of an institutional character.

4. Structural similarities of partnerships established by local government units and the forest and wood-based sector in Poland result from the conditions of the economic policy and public policies. These are determined by the natural monopoly of State Forests (in Polish: Państwowe Gospodarstwo Leśne Lasy Państwowe) as well as the high degree of institutionalization of the wood market in Poland (primary market). The functioning of a secondary market in the forest and wood-based sector, dispersed and territorially diversified, is subject to market mechanisms. However, due to the dependence on wood resources, local wood markets are determined by the impact of the primary market of an institutional character.

A research approach, applied in this paper, to the examination of the development of intermunicipal institutional partnerships may constitute a starting point for a study regarding intersectoral cooperation. In particular, it seems appropriate to carry out further research on spatial autocorrelation for individuals combining inter-municipal and intersectoral cooperation potential (institutional) with the resource potential of forestry (economic). This seems to be an important, prospective contribution to the search for an answer to the research question of institutional, industrial and environmental importance of symbiosis in natural economy [53,54], in which resources, although renewable, will always be insufficient.

The analysis of the selected examples from the forest and wood-based sector in Poland shows that the dynamics of integrated development of functional areas are determined by collaboration between and combination of the potential of different, both institutional (public) and market, entities.

Author Contributions: Conceptualization, L.W.; Data curation, T.P., E.M. and K.M.; Formal analysis, L.W. and J.C.; Funding acquisition, E.M.; Investigation, T.P. and J.C.; Methodology, L.W., T.P. and J.C.; Project administration, T.P.; Resources, L.W. and T.P.; Software, E.M.; Supervision, L.W.; Validation, J.C., E.M. and K.M.; Visualization, E.M. and K.M.; Writing—original draft, L.W.; Writing—review \& editing, L.W., E.M. and K.M.

Funding: This research received no external funding.

Acknowledgments: This research was prepared within the project "Scholarship support for Ph.D. students specializing in majors strategic for Wielkopolska's development", Sub-measure 8.2.2 Human Capital Operational Program, co-financed by European Union under the European Social Fund. This work was presented at the 9th International Scientific Conference WoodEMA 2016, The Path Forward for Wood Products: A Global Perspective, Baton Rouge, Louisiana, USA, 5-8 October 2016.

Conflicts of Interest: The authors declare no conflict of interest. 


\section{References}

1. Von Thünen, J. Isolated State: An English Edition of Der Isolierte Staat; Pergamon Press: Oxford, UK, 1826.

2. Sinclair, R. Von Thünen and urban sprawl. Ann. Am. Geog. Assoc. 1967, 57. [CrossRef]

3. Weber, A. Alfred Weber's Theory of the Location of Industries; Chicago University of Chicago Press: Chicago, IL, USA, 1909.

4. Christaller, W. Die Zentralen Orte in Süddeutschland. Eine Ökonomisch-Geographische Untersuchung über die Gesetzmässigkeit der Vorbereitung und Entwicklung der Siedlungen mit Städtischen Funktionen; wbg Academic: Darmstadt, Germany, 1933.

5. Hotelling, H. Stability in competition. Econ. J. 1929, 39, 41-57. [CrossRef]

6. Lösch, A. The nature of economic regions. South. Econ. J. 1938, 5, 71-78. [CrossRef]

7. Jones, C. Spatial economy and the geography of functional economic areas. Environ. Plan. B Urban Anal. City Sci. 2017, 44, 486-503. [CrossRef]

8. Isard, W. Game theory, location theory and industrial agglomeration. Reg. Sci. 1967, 18, 1-11. [CrossRef]

9. Krugman, P. Increasing returns and economic geography. J. Polit. Econ. 1991, 99, 483-499. [CrossRef]

10. Fujita, M.; Krugman, P.R. The new economic geography: Past, present and the future. Pap. Reg. Sci. 2004, 83, 139-164. [CrossRef]

11. Márquez, M.A.; Lasarte, E.; Lufin, M. The Role of Neighborhood in the Analysis of Spatial Economic Inequality. Soc. Indic. Res. 2017, 1-29. [CrossRef]

12. Porter, M.E. Regional Competitiveness in a Global Economy; The Brookings Institution: Washington, DC, USA, 2008.

13. Robertson, R. Globalization-Social Theory and Global Culture; Sage Publications: London, UK, 1992.

14. Swyngedouw, E. Neither Global nor Local: "Glocalization" and the Politics of Scale. In Spaces of Globalization, Reasserting the Power of the Local; Cox, K.R., Ed.; The Guilford Press: New York, NY, USA, 1997; pp. 137-166.

15. Swyngedouw, E. Globalisation or "Glocalisation"? Networks, Territories and Rescaling. Camb. Rev. Int. Aff. 2004, 17, 25-48. [CrossRef]

16. Słodowa-Hełpa, M. Interdyscyplinarna natura paradygmatu rozwoju-Uwarunkowania i propozycje usprawnienia dialogu. Nierówności Społeczne Wzrost Gospodarczy 2015, 41, 67-92.

17. Lessem, R.; Schieffer, A. Integral Economics: Releasing the Economic Genius of Your Society; Routledge: Oxon, UK, 2016.

18. GUS Forestry/Leśnictwo. Central Statistical Office. Warszawa; 2017. Available online: https://stat.gov. pl/files/gfx/portalinformacyjny/pl/defaultaktualnosci/5510/1/13/1/lesnictwo_2017.pdf (accessed on 21 March 2018).

19. Bergen, V.; Löwenstein, W.; Olschewski, R. Forstökonomie: Volkswirtschaftliche Ansätzefür eine Vernünftige Umwelt-und Landnutzung; Vahlen Franz: Munchen, German, 2013.

20. Ratajczak, E. Sektor Leśno-Drzewny w Zielonej Gospodarce; Wydawnictwo Instytutu Technologii Drewna: Poznań, Poland, 2013.

21. Chudobiecki, J.; Wanat, L. Industrial Symbiosis and Green Business Parks in The Wood-Based Sector in Poland. In Wood Processing and Furniture Manufacturing Challenges on the World Market; Chobanova, R., Ed.; WoodEMA: Zagreb, Croatia, 2015; pp. 221-228.

22. Kaputa, V.; Paluš, H.; Vlosky, R. Barriers for Wood Processing Companies to Enter Foreign Markets: A Case Study in Slovakia. Eur. J. Wood Wood Prod. 2016, 74, 109-122. [CrossRef]

23. Szewczuk, J. Przed jakimi wyzwaniami stoją samorządy i dlaczego muszą współpracować. In Wspótpraca Jednostek Samorzadu Terytorialnego Narzędziem Wsparcia Polskiej Polityki Rozwoju; Potkański, T., Ed.; Związek Miast Polskich: Poznań, Poland, 2016; pp. 13-25.

24. Wanat, L.; Potkański, T. Barriers for Effective Regional Leadership in Time of Crisis. Intercathedra 2011, 4, 75-79.

25. Backhaus, N. Zugänge zur Globalisierung: Konzepte, Prozesse, Visionen; Universität Zürich Geographisches Institute: Zürich, Switzerland, 2003.

26. Florida, R. Who's Your City? How the Creative Economy Is Making Where to Live the Most Important Decision of Your Life; Vintage Canada: Toronto, ON, Canada, 2010.

27. Wanat, L.; Lis, W. Promotion of Best Practices-Project Proposal for the Wood Industry in Poland. Intercathedra 2009, 25, 151-155. 
28. Wassermann, S.; Faust, K. Social Network Analysis: Methods and Applications; Cambridge University Press: Cambridge, UK, 2007.

29. Wanzenböck, I.; Scherngell, T.; Brenner, T. Embeddedness of Regions in European Knowledge Networks: A Comparative Analysis of Inter-Regional R\&D Collaborations, Co-Patents and Co-Publications. Ann. Reg. Sci. 2014, 53, 337-368.

30. Möller, K.; Rajala, A. Rise of Strategic Nets-New Modes of Value Creation. Ind. Mark. Manag. 2007, 36, 895-908. [CrossRef]

31. Cook, P.; Memedovic, O. Strategies for Regional Innovation Systems: Learning Transfer and Applications; United Nations Industrial Development Organization: Vienna, Austria, 2003.

32. Fritsch, M.; Kauffeld-Monz, M. The Impact of Network Structure on Knowledge Transfer: An Application of Social Network Analysis in The Context of Regional Innovation Networks. Ann. Reg. Sci. 2010, 44, 21. [CrossRef]

33. Potkański, T. Wspótpraca Jednostek Samorządu Terytorialnego Narzędziem Wsparcia Polskiej Polityki Rozwoju; Związek Miast Polskich: Poznań, Poland, 2016.

34. Potkański, T.; Wanat, L. Dylematy rozwoju miejskich obszarów funkcjonalnych z perspektywy partnerstw międzysamorzadowych. Studia KPZK 2017, 1, 235-245.

35. Grau, B.C.; Horrocks, I.; Kazakov, Y.; Sattler, U. A logical framework for modularity of ontologies. In Proceedings of the 20th International Joint Conference on Artifical Intelligence, Hyderabad, India, 6-12 January 2007; Morgan Kaufmann Publisher: San Francisco, CA, USA, 2007.

36. Sporns, O. The human connectome: A complex network. Ann. N. Y. Acad. Sci. 2011, 1224, 109-125. [CrossRef] [PubMed]

37. Wanat, L. Dobre praktyki współpracy międzysamorządowej. In Wspótpraca Jednostek Samorzadu Terytorialnego Narzędziem Wsparcia Polskiej Polityki Rozwoju; Potkański, T., Ed.; Związek Miast Polskich: Poznań, Poland, 2016; pp. 141-163.

38. Graczyk, A. Lasy oraz gospodarka leśna w strategii wzrostu gospodarczego i rozwoju zrównoważonym. In Polskie lasy i Leśnictwo w Europie; Święcicki, Z.Ś., Ed.; Centrum Informacyjne Lasów Państwowych: Warszawa, Poland, 2005; pp. 85-86.

39. Pokusa, T. Klaster Drzewny, Klaster Energii Odnawialnych, Klaster Chemiczny. Możliwości Funkcjonowania i Rozwoju Klastra Rekreacyjno-Ruchowego w Województwie Opolskim, Wyższa Szkoła Zarządzania i Administracji. Opole, 2011. Available online: https://www.efs.2007-2013.gov.pl/ AnalizyRaportyPodsumowania/baza_projektow_badawczych_efs/Documents /8_Klaster_drzewny_ energii\%20odnawialnych_chemiczny.pdf (accessed on 29 August 2018).

40. Luo, X.; Slotegraaf, R.J.; Pan, X. Cross-functional "coopetition": The simultaneous role of cooperation and competition within firms. J. Mark. 2006, 70, 67-80. [CrossRef]

41. Lacam, J.S.; Salvetat, D. The complexity of co-opetitive networks. Bus. Process Manag. J. 2017, 23, $176-195$. [CrossRef]

42. Voorn, B.; van Genugten, M.L.; van Thiel, S. The efficiency and effectiveness of municipally owned corporations: A systematic review. Local Gov. Stud. 2017, 43, 820-841. [CrossRef]

43. Giacomini, D.; Sancino, A.; Simonetto, A. The introduction of mandatory inter-municipal cooperation in small municipalities: Preliminary lessons from Italy. Int. J. Public Sect. Manag. 2018, 31, 331-346. [CrossRef]

44. Chudobiecki, J.; Potkański, T.; Wanat, L. Intermunicipal and Inter-sectoral Cooperation as a Tool Supporting Local Economic Development. In Proceedings of the 9th International Scientific Conference on The Path Forward for Wood Products: A Global Perspective, Baton Rouge, LA, USA, 5-8 October 2016; WoodEMA: Zagreb, Croatia, 2016.

45. Popek, M.; Wanat, L. Price versus non-price factors of sector competitiveness: Case study of the round wood market in Poland. Intercathedra 2014, 2, 71-77.

46. Mourao, P. The Economics of Illusion-A discussion based on Fiscal Illusion. J. Public Financ. Public Choice 2007, 25, 67-86.

47. Mourao, P. Towards a Puviani's fiscal illusion index. Hacienda Pública Española 2008, 187, 49-86.

48. Paluš, H.; Parobek, J.; Vlosky, R.; Motik, D.; Oblak, L.; Jošt, M.; Glavonjić, B.; Dudík, R.; Wanat, L. The status of chain-of-custody certification in the countries of Central and South Europe. Eur. J. Wood Wood Prod. 2018, 76, 699-710. [CrossRef] 
49. Bivand, R.S. Regression modeling with spatial dependence: An application of some class selection and estimation methods. Geog. Anal. 1984, 16, 25-37. [CrossRef]

50. Bivand, R.; Piras, G. Comparing implementations of estimation methods for spatial econometrics. J. Stat. Softw. 2015, 63. [CrossRef]

51. Miller, H.J. Tobler's first law and spatial analysis. Ann. Assoc. Am. Geog. 2004, 94, 284-289. [CrossRef]

52. Anselin, L. Local Indicators of Spatial Association-LISA. Geog. Anal. 1995, 27, 93-115. [CrossRef]

53. Kusiak, W.; Mikołajczak, E.; Wanat, L. Institutional and Industrial Symbiosis Case Study of Cooperation for Development in Forestry and Wood-Based Sector. In Proceedings of the 11th International Scientific Conference on Increasing the Use of Wood in the Global Bio-Economy, Belgrade, Serbia, 2018; WoodEMA: Zagreb, Croatia, 2018.

54. Abreu, M.; De Groot, H.L.F.; Florax, R.J.G.M. Space and Growth: A Survey of Empirical Evidence and Methods. Reg. Dev. 2005, 21, 13-44. [CrossRef]

(C) 2018 by the authors. Licensee MDPI, Basel, Switzerland. This article is an open access article distributed under the terms and conditions of the Creative Commons Attribution (CC BY) license (http:/ / creativecommons.org/licenses/by/4.0/). 